\title{
Experimental Autoimmune Encephalomyelitis Potentiates Mouse Mast Cell Protease 4-Dependent Pressor Responses to Centrally or Systemically Administered Big Endothelin-1 ${ }^{\text {[ }}$
}

\author{
Louisane Desbiens, Catherine Lapointe, Louis Gendron, Marjan Gharagozloo, \\ Laurence Vincent, Gunnar Pejler, Denis Gris, and Pedro D'Orléans-Juste
}

Department of Pharmacology and Physiology, Medical School, Université de Sherbrooke, Sherbrooke, Québec, Canada (L.D., C.L., L.G., M.G., L.V., D.G., P.D'.O.J.); Department of Medical Biochemistry and Microbiology, Uppsala University BMC, Uppsala, Sweden (G.P.); and Department of Anatomy, Physiology and Biochemistry, Swedish University of Agricultural Sciences, Uppsala, Sweden (G.P.)

Received December 20, 2018; accepted June 25, 2019

\begin{abstract}
Multiple sclerosis is a neurodegenerative disease affecting predominantly female patients between 20 and 45 years of age. We previously reported the significant contribution of mouse mast cell protease 4 (mMCP-4) in the synthesis of endothelin-1 (ET-1) in healthy mice and in a murine model of experimental autoimmune encephalomyelitis (EAE). In the current study, the cardiovascular effects of ET-1 and big endothelin-1 (big-ET-1) administered systemically or intrathecally were assessed in the early preclinical phase of EAE in telemetry instrumented/conscious mice. Chymase-specific enzymatic activity was also measured in the lung, brain, and mast cell extracts in vitro. Finally, the impact of EAE immunization was studied on the pulmonary and brain mRNA expression of different genes of the endothelin pathway, interleukin-33 (IL-33),
\end{abstract}

and monitoring of immunoreactive tumor necrosis factor- $\alpha$ $(T N F-\alpha)$. Systemically or intrathecally administered big-ET-1 triggered increases in blood pressure in conscious mice. One week post-EAE, the pressor responses to big-ET-1 were potentiated in wild-type (WT) mice but not in MMCP-4 knockout (KO) mice. EAE triggered mMCP-4-specific activity in cerebral homogenates and peritoneal mast cells. Enhanced pulmonary, but not cerebral preproendothelin-1 and IL-33 mRNA were found in $\mathrm{KO}$ mice and further increased 1 week post-EAE immunization, but not in WT animals. Finally, TNF- $\alpha$ levels were also increased in serum from mMCP-4 KO mice, but not WT, 1 week post-EAE. Our study suggests that mMCP-4 activity is enhanced both centrally and systemically in a mouse model of EAE.

\section{Introduction}

Multiple sclerosis (MS), mostly caused by complex cellular interactions (Duffy et al., 2014; Cheng et al., 2017; Luo et al., 2017; Ponath et al., 2018), is a chronic autoimmune and degenerative disease of the central nervous system (CNS) associated with inflammation, tissue insult, and neuromotor dysfunction (Lublin, 2005; Compston and Coles, 2008; Huang et al., 2016). In MS patients, albeit vascular and endothelial integrities are unaffected (Mincu et al., 2018), several cardiovascular comorbidities such as hypertension, heart

This project was financially supported by the Canadian Institutes for Health Research [MOP-57883] as well as by the Etienne Lebel Clinical Research Center of the Centre Hospitalier Universitaire de Sherbrooke. L.D. holds Ph.D. studentship from the Fonds de recherche du Québec-Santé (FRQS). M.G. holds Ph.D. studentship from the FRQS in partnership with Multiple Sclerosis Society of Canada. P.D'.O.-J. is the recipient of a Joseph C. Edwards Cardiology Chair. D.G. is a recipient of a Junior 2 scholarship from the FRQS. https://doi.org/10.1124/jpet.118.256016.

S This article has supplemental material available at jpet.aspetjournals.org. diseases, and cardio-metabolic disorders have been reported (Ewanchuk et al., 2018).

Experimental autoimmune encephalomyelitis (EAE) reproduces the major cardinal signs of neurodegeneration and associated spinal cord lesions occurring in MS (Kipp et al., 2012; Ben-Nun et al., 2014). In EAE, a significant contribution of mast cell (MC) degranulation to the etiology of the neurodegenerative disease was initially reported by Secor et al. (2000). However, this concept was later challenged since complete removal of MCs in a Kit-independent MC-deficient strain had no significant impact on the development of the disease (Feyerabend et al., 2011). Directly targeting MCs in MS thus remains an open question.

Among several pro- and anti-inflammatory factors, MCs secrete chymase, a serine protease that hydrolyzes endothelin-1 (ET-1) from its precursor, big endothelin-1 (big-ET-1), in vitro (Petrie et al., 2001; Borland et al., 2005; Simard et al., 2009). Mouse MCs express several chymases, of which mouse mast cell protease $4(\mathrm{mMCP}-4)$ is the most functionally similar to its

ABBREVIATIONS: big-ET-1, big endothelin-1; CNS, central nervous system; EAE, experimental autoimmune encephalomyelitis; ECE, endothelinconverting enzyme; $\mathrm{ET}$, endothelin; $\mathrm{ET}_{\mathrm{A}}$, endothelin A receptor; $\mathrm{ET}_{\mathrm{B}}$, endothelin $\mathrm{B}$ receptor; $\mathrm{ET}-1$, endothelin-1; HR, heart rate; IL-3, interleukin-33; $\mathrm{KO}$, knock out; MAP, mean arterial pressure; MC, mast cell; mMCP-4, mouse mast cell protease 4; MS, multiple sclerosis; prepro-ET-1, preproendothelin-1; TNF- $\alpha$, tumor necrosis factor- $\alpha$; WT, wild type. 
human counterpart, chymase 1 (Semaan et al., 2015). Indeed, recombinant mMCP-4 efficiently converts big-ET-1 to an intermediate precursor, ET-1 (1-31), which is then readily hydrolyzed to ET-1 via the ubiquitous neutral endopeptidase 24/11 (Fecteau et al., 2005; Semaan et al., 2015).

Antagonism of endothelin $\mathrm{A}\left(\mathrm{ET}_{\mathrm{A}}\right)$ receptors for ET-1 reduces the severity of EAE in rats (Shin et al., 2001), whereas blocking the endothelin $\mathrm{B}\left(\mathrm{ET}_{\mathrm{B}}\right)$ receptors indirectly inhibits oligodendrocyte progenitor cell differentiation as well as remyelination in mice (Hammond et al., 2015). Plasma levels of ET-1 are elevated in patients with MS (Haufschild et al., 2001; Pache et al., 2003) and the use of a mixed $\mathrm{ET}_{\mathrm{A}} / \mathrm{ET}_{\mathrm{B}}$ antagonist, bosentan, normalizes cerebral blood flow in these patients (D'haeseleer et al., 2013). On the other hand, ET-1 administered either systemically in the conscious mouse (Semaan et al., 2015) or centrally in the nonanesthetized rat (Poulat et al., 1994), triggers a trademark protracted increase in blood pressure in vivo. To our knowledge, there is no evidence in the literature indicating that cardiovascular responses are prompted by centrally administered endothelins (ETs) in the conscious mouse model.

mMCP-4 is also involved in early neuromotor disabilities associated with EAE (Desbiens et al., 2016). We have previously shown that genetic repression of mMCP-4 improved clinical signs and reduced spinal cord damage afforded by EAE in the mouse model (Desbiens et al., 2016). Furthermore, EAE triggers a significant increase in $\mathrm{mMCP}-4 \mathrm{mRNA}$ levels in the CNS as well as production of cerebral immunoreactive ET-1. However, an open question remains: does EAE trigger an increase in mMCP-4 activity outside the CNS as well? MC degranulation products are mediators of the allergic response to EAE outside the CNS (Tanzola et al., 2003). In addition, the lungs have been shown to be the niche in which self-reactive $\mathrm{T}$ cells are activated, allowing them to enter the target tissues such as the CNS where they trigger pathogenic events associated with EAE (Odoardi et al., 2012).

Inflammation in MS is associated with a cytokine storm within the CNS (Link, 1998). With regard to the present study, interleukin-33 (IL-33) reduces neuronal damage in the EAE model by suppressing interleukin-17 and interferon $\gamma$ (Jiang et al., 2012). Furthermore, repression of IL-33 increases neuronal damage in EAE mice with specific impact on immune and neural cells (Xiao et al., 2018). In addition, another cytokine, tumor necrosis factor- $\alpha$ (TNF- $\alpha$ ), increases the expression of IL-33 in human epidermal keratinocytes as well as in psoriasis (Balato et al., 2014), and nonselective TNF- $\alpha$ blockers enhance demyelination in MS patients (van Oosten et al., 1996; Dreyer et al., 2016).

Of relevance to the present study, Piliponsky et al. (2012) have shown that TNF- $\alpha$ is a substrate for mMCP-4 in a mouse model of sepsis and Waern et al. (2013) showed that IL-33 is a preferred substrate for chymase in allergic airway inflammation. Thus, in conditions of chronic repression of the murine chymase, one would expect an increase in the levels of IL-33 as well as TNF- $\alpha$, particularly in inflammatory settings.

The aim of the present study was to investigate, in the mouse model of MS, whether mMCP-4 activity is modulated solely in the CNS or if it can be extended to systemic circulation. Our central hypothesis is that EAE enhances mMCP-4-dependent conversion and thus biologic activity of the ET-1 precursor, big-ET-1, within and outside the central nervous system.

\section{Material and Methods}

Mice. C57Bl/6 mice genitors were purchased from Charles River Canada (Montréal, QC, Canada) and mMCP-4 knockout (KO) mice genitors were provided by Dr. Gunnar Pejler (Uppsala University, Sweden) and were bred in our facility. The mMCP-4 KO mice were backcrossed for over 10 generations with $\mathrm{C} 57 \mathrm{Bl} / 6$ congeners; therefore, they are highly congenial with the later strain (Tchougounova et al., 2003) as previously reported (Desbiens et al., 2016). We and others had also previously reported the complete loss of chymasedependent hydrolytic activity in mMCP-4 KO mice in vivo as well as in tissues or MCs derived from this mouse strain (Hendrix et al., 2013; Houde et al., 2013; Semaan et al., 2015).

All animals (female mice, 8-10 weeks old) were kept at constant room temperature $\left(23^{\circ} \mathrm{C}\right)$ and humidity $(78 \%)$ under a controlled 12-hour light/dark cycle. Mice had free access to standard chow and tap water ad libitum. Animal care and experimentations were carried out in accordance with the Guide for the Care and Use of Laboratory Animals as adopted and promulgated by the U.S. National Institutes of Health and were approved by the Ethics Committee on Animal Research of the Université de Sherbrooke in accordance with the guidelines of the Canadian Council on Animal Care.

Experimental Autoimmune Encephalomyelitis. Induction of EAE was performed in accordance with Miller et al. (2007). In brief, a 1:1 emulsion mixture of myelin oligodendrocyte glycoprotein-35-55 (Genemed Synthesis Inc., San Antonio, TX) and Freund's complete adjuvant (Sigma-Aldrich, St-Louis, MO) supplemented with $10 \mathrm{mg} / \mathrm{ml}$ of heat-killed Mycobacterium tuberculosis H37RA (Difco Laboratories, Detroit, MI) was prepared. Female mice (8-10 weeks old) were injected subcutaneously at two sites $(100 \mu \mathrm{l}$ per site) adjacent to the tail with the emulsion. Pertussis toxin (200 ng) (List Biologic Laboratories Inc., Campbell, CA) was administered intraperitoneally on the day of immunization. Mice were scored daily using the following scale to assess clinical scores: 0 , no sign of clinical disease; 0.5 , partial tail paralysis (loss of tip tail tonus); 1 , tail flaccidity or hind limb weakness; 2, limp tail and weakness in limb; 3, partial hind limb paralysis; 4, total hind limb paralysis; and 5, moribund state or death.

RNA Extraction and Quantitative Real-Time Polymerase Chain Reaction. RNA from the right lung lobes of healthy or 1 week post-EAE mice was extracted with the RNeasy Fibrous Tissue Mini Kit (Qiagen, Hilden, Germany) according to the manufacturer's instructions. Briefly, tissues were homogenized with tissue grinder Scilogex D-160 homogenizer (Rocky Hill, CT). All steps were followed as mentioned by the manufacturer except for treatment with DNase, where $2 \mu \mathrm{l}$ of DNase (Omega Bio-Tek, Norcross, GA) was diluted in $78 \mu \mathrm{l}$ of RDD buffer ( Qiagen) and added to the column of the extraction kit for 30 minutes at room temperature. After a few additional steps, an optional centrifugation step at maximal speed for 1 minute was performed prior to elution with $40 \mu \mathrm{l}$ of RNase-free water. The RNA eluate was filtered once more through the column before final centrifugation at 10,000g for 1 minute.

RNA from the right brain hemispheres derived from healthy or 1 week post-EAE mice was extracted using $1 \mathrm{ml}$ of RiboZol reagent (Amresco Inc., Solon, OH). Tissues were homogenized with a glassTeflon homogenizer. Chloroform (200 $\mu$ l) (J.T. Baker, Central Valley, PA) was added to each tube and incubated at room temperature for 3 minutes followed by centrifugation at $12,000 \mathrm{~g}$ for 15 minutes at $4^{\circ} \mathrm{C}$. Nonopaque supernatants were collected and $500 \mu \mathrm{l}$ of isopropanol (Fisher Scientific, Ottawa, ON, Canada) was added for RNA precipitation and incubated 10 minutes at room temperature followed by centrifugation at $12,000 \mathrm{~g}$ for 10 minutes at $4^{\circ} \mathrm{C}$. Pellets were washed in $1 \mathrm{ml} 75 \%$ ethanol followed by a $7500 \mathrm{~g}$ centrifugation step at $4^{\circ} \mathrm{C}$ for 5 minutes before being redissolved in $100 \mu \mathrm{l}$ of diethyl pyrocarbonate water and incubated at $55^{\circ} \mathrm{C}$ for 10 minutes.

RNA concentration was determined by absorbance at $\mathrm{A}_{260}$. We used $1 \mu \mathrm{g}$ of RNA for subsequent experiments. cDNA was synthesized using an oligo(dT) ${ }_{12-18}$ primer (Invitrogen, Carlsbad, CA), deoxyribonucleotide triphosphate mix at $10 \mu \mathrm{M}$ each (Thermo Scientific, Waltham, MA), 
and SuperScript III buffer with dithiothreitol, RNaseOUT, and SuperScript III (Invitrogen). Quantitative polymerase chain reaction was performed for actin, preproendothelin-1 (prepro-ET-1), endothelin-converting enzyme (ECE) $1 \mathrm{a}, \mathrm{ET}_{\mathrm{A}}$ and $\mathrm{ET}_{\mathrm{B}}$ receptors, and IL-33 by monitoring in real time the fluorescence increase of the SYBR Green using Perfecta SYBR Green SuperMix, Low ROX (Quanta Biosciences, Gaithersburg, MD) and the MX3000P Multiplex Quantitative PCR System (Agilent Technologies, Santa Clara, CA). Primers (IDT, Coralville, IA) were used at final concentration of $300 \mathrm{nM}$ per primer and sequences were designed as follows:

Prepro-ET-1: Forward 5'-GCA CAA CCG AGC ACA TTG-3';

Prepro-ET-1: Reverse 5'-CCA GCC AGC ATG GAG AGT-3';

ECE1a: Forward 5'-GCG GGG TC CTT CTT CCT GGG GAA-3';

ECE1a: Reverse 5'-CTG CAG GGA AGA AGC CAG GAG GGG$3^{\prime}$;

$\mathrm{ET}_{\mathrm{A}}$ : Forward 5'-CAA CCA TTA CGC CAC AGA-3';

$\mathrm{ET}_{\mathrm{A}}$ : Reverse 5'-CAG GAA AGA CCC ATT GGC-3';

$\mathrm{ET}_{\mathrm{B}}$ : Forward 5'-TCA ACA CCG GAT ATA TTC ACG GGC-3';

$\mathrm{ET}_{\mathrm{B}}$ : Reverse 5'-GCT CTG CTG AAG TGC TGA CTA AGA-3';

IL-33: Forward 5'-TGA GAC TCC GTT CTG GCC TC-3';

IL-33: Reverse 5'-CTC TTC ATG CTT GGT ACC CGA T-3';

$\beta$-actin: Forward 5 -GAT CAA GAT CAT TGC TCC TCC TGA GC-3'; and

$\beta$-actin: Reverse: $5^{\prime}$-GCA GCT CAG TAA CAG TCC GCC TAG$3^{\prime}$.

The cycle profile was: 10 minutes at $95^{\circ} \mathrm{C}$, followed by 40 cycles of denaturation for 30 seconds at $95^{\circ} \mathrm{C}$, annealing for 1 minute at $60^{\circ} \mathrm{C}$, and extension for 1 minute at $72^{\circ} \mathrm{C}$, followed by final denaturation for 1 minute at $95^{\circ} \mathrm{C}, 30$ seconds at $55^{\circ} \mathrm{C}$, and 30 seconds at $95^{\circ} \mathrm{C}$ for prepro-ET-1, ECE1a, and IL-33. The annealing time for ET receptor genes was 30 seconds at $60^{\circ} \mathrm{C}$. The fluorescence was measured after each annealing period during the 40 cycles and the complete dissociation curve was constructed between the 30 -second period at $55^{\circ} \mathrm{C}$ and the final 30 seconds at $95^{\circ} \mathrm{C}$.

Since $\beta$-actin levels were stable between healthy and immunized mice, the latter mRNA was used as the internal control for normalization and relative expressions of prepro-ET-1, ECE1a, $\mathrm{ET}_{\mathrm{A}}$ and $\mathrm{ET}_{\mathrm{B}}$ receptors, and IL-33 were calculated using the $2^{-\Delta \Delta \mathrm{CT}}$ method.

Hemodynamic Studies in Conscious Mice. Mice were implanted with radio telemetry transmitters (TA11PA-C10; Data Science International, St. Paul, MN). Mice were anesthetized with ketamine/xylazine (87/13 mg/kg, i.m.). The left common carotid artery was isolated and the catheter of the telemetry probe was implanted into the aortic arch. The body of the transmitter was placed subcutaneously into the right flank of the animal. An analgesia protocol was maintained for 24 hours after surgery with buprenorphine $(0.1 \mathrm{mg} / \mathrm{kg}$, given subcutaneously every 6-9 hours). In accordance with the timeline illustrated in Fig. 1, a postoperative recovery period of 7-10 days was allowed prior to recording and injections.

All mice were trained for 2 days in contention cages and during two additional days with intracaudal vein injection of saline. Mice were subsequently placed back in contention cages and a first dose of ET-1 ( $1 \mathrm{fmol} / \mathrm{kg}$ ) (Enzo Life Sciences, Farmingdale, NY) or big-ET-1 (10 or $100 \mathrm{fmol} / \mathrm{kg}$ ) (Phoenix Pharmaceuticals Inc., Burlingame, CA) was injected intravenously in a total volume of $100 \mu \mathrm{l}$. Mice were then immediately rehoused. After 2 days, a second dose of peptide ( $0.1 \mathrm{pmol} / \mathrm{mouse}$ for ET- 1 , or 0.5 or $5 \mathrm{pmol} / \mathrm{mouse}$ for big-ET-1) was administered intrathecally by an experienced experimenter as previously described (Fairbanks, 2003). Briefly, mice were maintained by the hips between the thumb and index fingers to open the space between the L5 and L6 vertebrae. Mice were injected $5 \mu \mathrm{l}$ of the agonists with $10 \mu$ l Hamilton syringes mounted with a 301/2G needle and subsequently released in their respective cages. Three days later, mice were EAE induced for a period of 7 days prior to intrathecal administration of the agonist followed by a second intravenous injection done 2 days later. Recording of hemodynamic parameters [mean arterial pressure (MAP), systolic blood pressure, diastolic blood pressure, and heart rate (HR)] was initiated 5 minutes before the contention of the animal for the drug administration, to determine the basal pressure, and up to 30 minutes post agonist injections. Data points were recorded every 30 seconds with the acquisition software Dataquest ART 4.33 (DSI, St Paul, MN). Each mouse was administered only one agonist. All data were analyzed with the Dataquest ART 4.33 analysis software. Blood pressure variations $(\Delta)$ obtained after the injection of each agonist were calculated as the difference between blood pressure increases postinjection and basal pressure recorded prior to administration of each agent.

Measurement of Endogenous IL-33, ET-1, and TNF- $\alpha$ Levels. For the measurement of TNF- $\alpha$ levels, frozen left-brain hemispheres or left lung lobes were weighed and homogenized in $1 \mathrm{ml}$ for lung tissues or $2 \mathrm{ml}$ for brain tissues of ice-cold lysis buffer (Cell Signaling Technology, Beverly, MA) supplemented with protease inhibitor cocktail (Cell Signaling Technology) using a glass-Teflon homogenizer. Tissue lysates were centrifuged at $13,000 \mathrm{~g}$ and $4^{\circ} \mathrm{C}$ for 20 minutes and supernatants were transferred to new tubes. Serum was obtained by full-speed centrifugation of blood samples for 20 minutes. Serum or tissue homogenate TNF- $\alpha$ levels were determined using the Mouse TNF- $\alpha$ Quantikine ELISA Kit (R\&D Systems, Minneapolis, MN), according to the manufacturer's instructions. The concentrations of TNF- $\alpha$ are expressed in picograms per milliliter. On the other hand, for measurement of ET-1 and IL-33 levels the frozen left-brain hemispheres of left lung lobes were weighed and homogenized in two volumes of $500 \mu \mathrm{l}$ of a chloroform:methanol (1:4) solution and then purified on a DSC-18 solid phase extraction column (Supelco, Bellefonte, PA) and eluted in acetonitrile:water:trifluoroacetic acid (ACN 60\%: $\mathrm{H}_{2} \mathrm{O}$ 40\%:TFA $0.1 \%$ ). The collected eluates were then speed vacuumed-dried overnight before reconstitution in PBS supplemented with 1/32 mouse plasma, and then endogenous ET-1 or IL-33 was measured using the Quantikine ELISA kit from R\&D Systems according to the manufacturer's instructions. The concentrations of IL-33 and ET-1 are expressed in picograms per milliliter and picograms per milligrams, respectively.

Peritoneal Mast Cell Isolation. MCs from the peritoneal cavity were isolated from healthy and 1 week post-EAE mice and used for measurement of chymase activity. Mice anesthetized with ketamine/ xylazine (87/13 mg/kg, i.m.) were injected with $5 \mathrm{ml}$ of isolation buffer [PBS ( $\mathrm{pH} 7.4$ ) containing $1 \mathrm{mg} / \mathrm{ml}$ of bovine serum albumin and $0.5 \mathrm{mg} / \mathrm{ml}$ of heparin] in the peritoneal cavity. The peritoneal fluids were collected following 1-minute abdominal massage and centrifuged at $200 \mathrm{~g}$ for 5 minutes. Pellets were suspended in $1 \mathrm{ml}$ RPMI 1640 medium containing $2 \mathrm{mM}$ of L-glutamine, $100 \mathrm{U} / \mathrm{ml}$ of

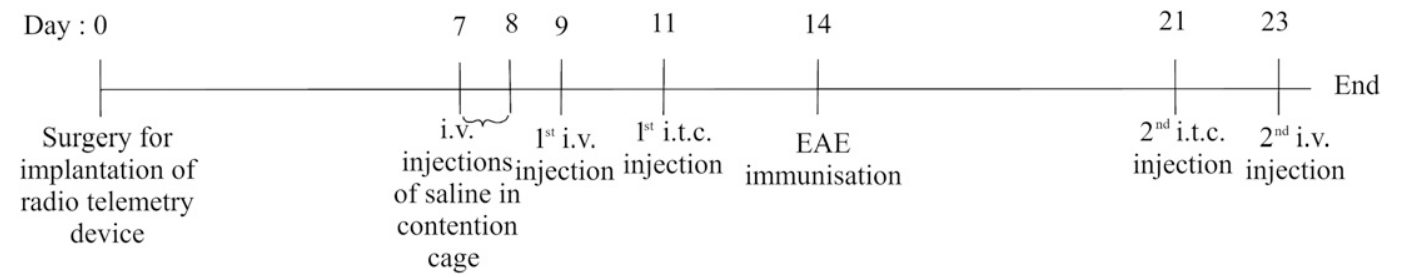

Fig. 1. Timeline regarding the treatments for hemodynamic studies in conscious mice. 
penicillin, and $1 \mathrm{mg} / \mathrm{ml}$ of bovine serum albumin, and subsequently incubated for 1 hour at $37^{\circ} \mathrm{C}$ in tissue culture dishes $(35 \times 10 \mathrm{~mm})$ to sediment and let the macrophages and leukocytes adhere to the plastic surface of the dish, thus allowing purification of the MCs. RPMI 1640 medium and nonadherent cells were collected and centrifuged at $200 \mathrm{~g}$ for 5 minutes. Pellets were suspended in $1 \mathrm{ml}$ isolation buffer and cells were counted according to the Moore and James (1953) method with toluidine blue. A final centrifugation was performed at $200 \mathrm{~g}$ for 5 minutes and pellets were suspended in $\mathrm{PBS}$ ( $\mathrm{pH} 8$ ) in a concentration of $10,000 \mathrm{MCs} / \mu \mathrm{l}$ and used as described subsequently.

Cerebral Protein Extraction. Chymase-containing homogenates were first extracted from the left-brain hemisphere of healthy or 1 week post-EAE mice as described previously (Kakizoe et al., 2001). The brain was homogenized in 10 volumes (v/w) of $20 \mathrm{mM}$ sodium phosphate buffer ( $\mathrm{pH}$ 7.4) using a glass-Teflon homogenizer. The homogenate was then centrifuged at $18,000 \mathrm{~g}$ for 30 minutes at $4^{\circ} \mathrm{C}$. The supernatant was discarded since it contained soluble proteins that might interfere with the chymase activity. These three steps were repeated twice. Following the last centrifugation, the pellet was suspended in five volumes ( $/ \mathrm{w}$ ) of $10 \mathrm{mM}$ sodium phosphate buffer $(\mathrm{pH} 7.4), 2 \mathrm{M} \mathrm{KCl}$, and $0.1 \%$ Triton $\mathrm{X}-100$. The homogenate was agitated overnight at $4^{\circ} \mathrm{C}$ and subsequently centrifuged at $18,000 \mathrm{~g}$ for 30 minutes at $4^{\circ} \mathrm{C}$. The resulting supernatant was kept as the final chymase extract at $-80^{\circ} \mathrm{C}$ until used. Protein concentrations were determined by the Bradford method with $\gamma$-globulin (Sigma-Aldrich) as the standard.

Pulmonary Protein Extraction. Chymase-containing homogenates were extracted from the left lobes of the lung from healthy or 1 week post-EAE mice as previously described (Houde et al., 2013). Tissues were homogenized in two volumes (200 $\mu \mathrm{l})$ of PBS (pH 7.4) using a glass-Teflon homogenizer. The homogenates were then centrifuged at $18,000 \mathrm{~g}$ for 20 minutes at $4^{\circ} \mathrm{C}$. The resulting supernatants were collected and kept at $-80^{\circ} \mathrm{C}$ until used. Protein concentrations were determined by the Bradford method with $\gamma$-globulin as the standard.

Measurement of Chymase Enzymatic Activity. The brain chymase extracts were diluted to obtain a final concentration of $1 \mathrm{mg}$ protein $/ \mathrm{ml}$ and incubated for 20 minutes at $37^{\circ} \mathrm{C}$, with vortex mixing every 5 minutes with cathepsin G inhibitor I (Cayman Chemical, Ann Harbor, MI) at a final concentration of $10 \mu \mathrm{M}$ to discriminate the chymase from cathepsin $\mathrm{G}$ activity. Lung chymase extracts were diluted to obtain a final concentration of $1 \mathrm{mg}$ protein $/ \mathrm{ml}$ and incubated for 20 minutes at $37^{\circ} \mathrm{C}$, with vortex mixing every 5 minutes. These solutions or peritoneal MC extracts (100,000 MCs) were placed in 96 -well plates. The chymase activity was determined by the hydrolysis rate of $10 \mu \mathrm{M}$ of the substrate, succinyl-Leu-Leu-Val-Tyr-7-amino-4-methylcoumarin (Peptide Institute inc., Osaka, Japan), at $37^{\circ} \mathrm{C}$. The fluorescence of the released 7-amino-4-methylcoumarin molecule was measured with an Infinite M1000 spectrophotometer (Tecan Group Ltd., Männerdorf, Swiss) with $\lambda_{\mathrm{ex}}=370 \mathrm{~nm}$ and $\lambda_{\mathrm{em}}=460 \mathrm{~nm}$ for 15 minutes.

Statistical Analyses. All data are presented as mean \pm S.E.M. All statistical analyses were conducted using GraphPad Prism 7 software (GraphPad Software, La Jolla, CA). Statistical significance was reached when the $P$ value was below 0.05 and was determined using one-way ANOVA and multiple Student's $t$ tests.

\section{Results}

EAE-Induced Potentiation of Intravenously or Intrathecally Administered Big-ET-1. The impact of EAE immunization on basal hemodynamic parameters was investigated in telemetry-instrumented and conscious mice. First, prior to EAE treatments basal blood pressure parameters were similar in wild-type (WT) and mMCP-4 KO mice (MAP: $91.39 \pm 5.27$ and $92.96 \pm 6.15 \mathrm{~mm} \mathrm{Hg}$; systolic blood pressure: $101.67 \pm 6.19$ and $102.76 \pm 5.32 \mathrm{~mm} \mathrm{Hg}$; diastolic blood pressure: $81.59 \pm 6.07$ and $80.39 \pm 5.18 \mathrm{~mm} \mathrm{Hg}$; and HR: $659.44 \pm 19.34$ and $677.15 \pm 14.97 \mathrm{beats} / \mathrm{min}$, respectively). As shown in Fig. 2A, the induction of EAE did not affect the basal parameters. Figure 2B represents the typical timecourse profile of the MAP and HR responses to an intravenous or intrathecal injection of ET- 1 ( $1 \mathrm{fmol} / \mathrm{kg}$ or $0.1 \mathrm{pmol} / \mathrm{mouse}$, respectively) in healthy WT mice. In our experiments, we did not observe any variation in HR after injection of big-ET-1 or ET-1. We suggest that this is caused by the particularly elevated basal HR in conscious mice. Another explanation would be that the doses of agonists used in the present study were too low to induce increases in HR.

Figure 3A shows the maximal increase of the MAP after intravenous administration of big-ET-1 in conscious and unrestrained mice. Intravenous administration of big-ET-1 (10 or $100 \mathrm{fmol} / \mathrm{kg}$ ) prompted dose-dependent increases in MAP in healthy WT mice that were significantly potentiated in congeners 1 week post-EAE immunization $(P<0.01)$. In healthy mMCP-4 KO mice, we observed a significant reduction of the MAP increases when compared with WT congeners $(P<0.001)$ and no potentiation of the response to big-ET-1 post-EAE induction. Finally, intravenous administration of ET-1 (1 fmol/kg) prompted similar blood pressure responses in healthy or 1 week post-EAE immunization WT and mMCP-4 KO mice (Fig. 3B).

Similarly, intrathecally administered big-ET-1 (0.5 or $5 \mathrm{pmol} / \mathrm{mouse}$ ) increased MAP in healthy WT mice in a dosedependent fashion. Conversely, a decreased MAP was observed in healthy mMCP-4 KO mice $(P<0.05)$. The increases in MAP were significantly potentiated 1 week post-EAE in WT $(P<0.05)$ but not in EAE-induced mMCP-4 KO mice (Fig. 3C). In contrast, intrathecal administration of ET-1 $(0.1 \mathrm{pmol} / \mathrm{mouse})$ induced a similar blood pressure response in healthy and EAE-immunized WT or mMCP-4 KO mice (Fig. 3D). Figure 3, E and F shows the time-course profile of MAP increases in response to intrathecal administration bigET-1 (0.5 pmol/mouse) in WT or mMCP-4 KO mice, either under healthy conditions or 1 week post-EAE.

mMCP-4 Specific Activity in Mast Cells, Brains, and Lungs of EAE-Induced Mice. The hydrolytic activity on the fluorogenic substrate succinyl-Leu-Leu-Val-Tyr-7-amino4-methylcoumarin was measured in brain homogenates (Fig. 4A). We observed a linear increase in the fluorescence in brain extracts of healthy WT mice and to a lesser extent in EAEinduced WT congeners $(P<0.05$ when compared with healthy WT mice). Total hydrolytic activity was also significantly reduced in extracts from healthy or EAE-induced mMCP-4 KO mice when compared with healthy WT mice $(P<0.05)$.

Figure $4 \mathrm{~B}$ shows the hydrolytic activity of the same substrate in peritoneal MCs. As was the case with brain extracts, we observed a linear increase in the fluorescence in healthy WT but not mMCP-4 KO mice. One week post-EAE immunization the hydrolytic activity in peritoneal MCs derived from WT mice was abolished $(P<0.05$, when compared with healthy WT mice), whereas no effects of EAE induction on fluorescence were seen in MCs derived from mMCP-4 KO mice.

Hydrolytic activities were also measured in lung extracts (Fig. 4C). The maximal fluorescence, detected 15 minutes after initiation of the reaction, was not significantly different between homogenates derived from the two WT groups (healthy or EAE). In contrast, a significant decrease in maximal fluorescence was seen in extracts from healthy 
A

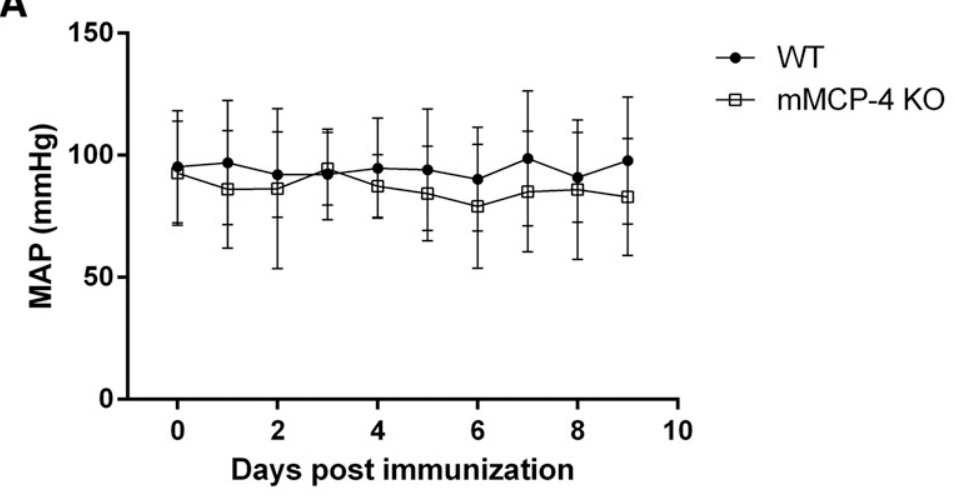

B

ET-1 $1 \mathrm{fmol} / \mathrm{kg}$ i.v.
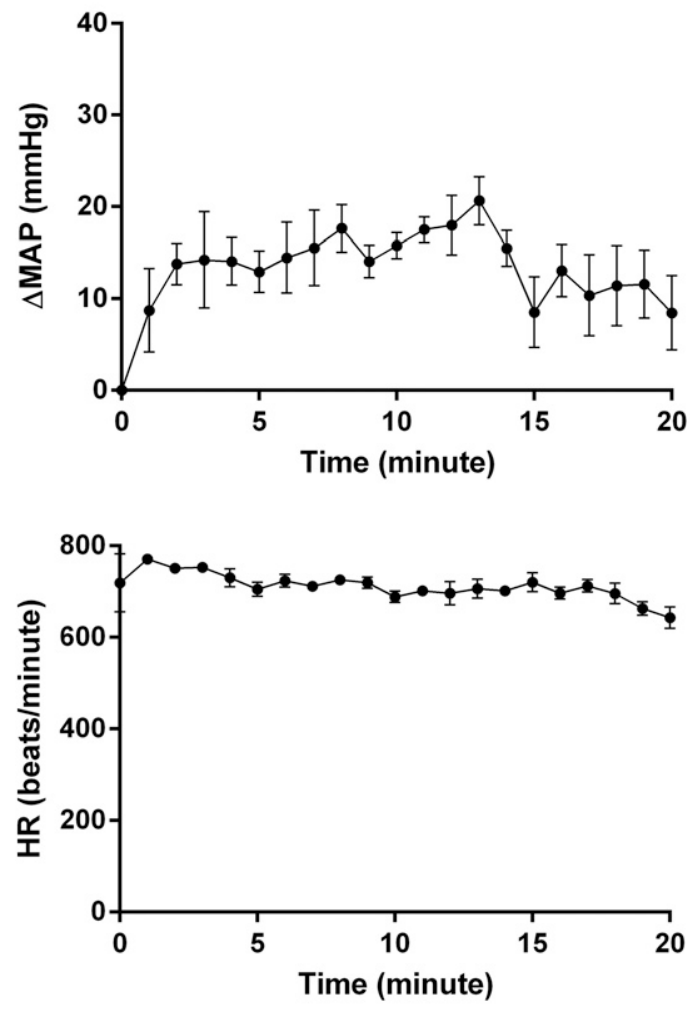

ET-1 0.1 pmol i.t.
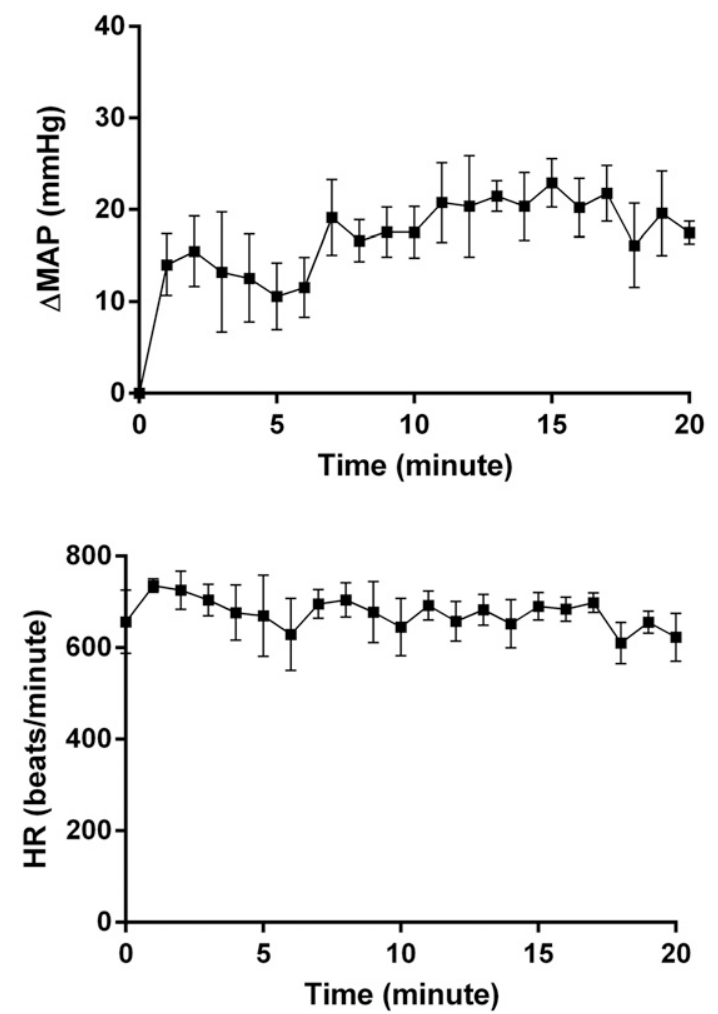

Fig. 2. (A) Effect of EAE in the preclinical phases on basal MAP in conscious mice. Each point corresponds to the mean \pm S.E.M. of WT ( $n=8)$ and mMCP-4 KO $(n=7)$ mice. (B) Typical time course profile of MAP variation (upper panels) and HR (lower panels) in healthy WT mice in response to exogenous intravenous administration of ET-1 ( $1 \mathrm{fmol} / \mathrm{kg}$ ) (left panels) or intrathecally administered ET-1 (0.1 pmol/mouse) (right panels). Each point corresponds to the mean \pm S.E.M. of the average of at least four different experiments.

mMCP-4 KO mice versus WT congeners $(P<0.05)$, with no influence of EAE on the hydrolytic activity in lung extracts from the KO strain.

Upregulation of Prepro-ET-1 mRNA in the Lungs of EAE-Induced KO Mice. We previously showed a significant increase in immunoreactive ET-1 in cerebral tissues of WT mice 1 week post EAE but not 2 weeks postimmunization (Desbiens et al., 2016).

Figure 5A shows the relative expression of cerebral and pulmonary prepro-ET-1 in WT and mMCP-4 KO mice. Lungs and brain mRNA samples were extracted from healthy or 1 week post-EAE mice and quantified using the $2^{-\Delta \Delta \mathrm{CT}}$ calculation method and $\beta$-actin as the housekeeping gene. The levels of prepro-ET- 1 mRNA in the brain did not differ among the four groups of mice studied. In pulmonary extracts, albeit no difference in the expression of prepro-ET-1 mRNA was detected in WT mice 1 week post-EAE immunization, an increase in prepro-ET-1 mRNA levels was found in healthy mMCP-4 KO mice when compared with WT congeners $(P<$ 0.05). Prepro-ET-1 mRNA levels were further increased 1 week post-EAE immunization in the KO congeners $(P<$ 0.001 compared with healthy WT mice; $P<0.001$ compared with healthy mMCP-4 KO mice).

We also measured the cerebral and pulmonary expression of ECE1a with no differences measured in either healthy or postEAE immunization WT or mMCP-4 KO mice (brain: healthy $\mathrm{WT}=1.00 \pm 0.36$, WT EAE $=1.17 \pm 0.41$, healthy mMCP-4 $\mathrm{KO}=1.24 \pm 0.23$, and $\mathrm{mMCP}-4 \mathrm{KO} \mathrm{EAE}=1.64 \pm 0.54$; lungs: 


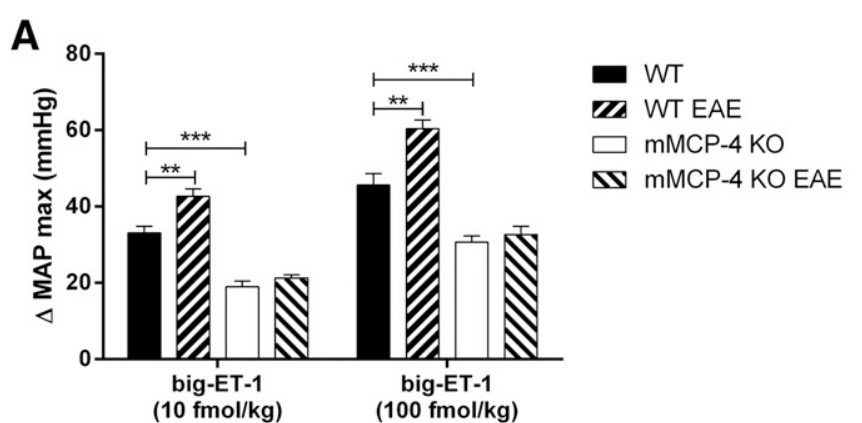

intravenous treatment

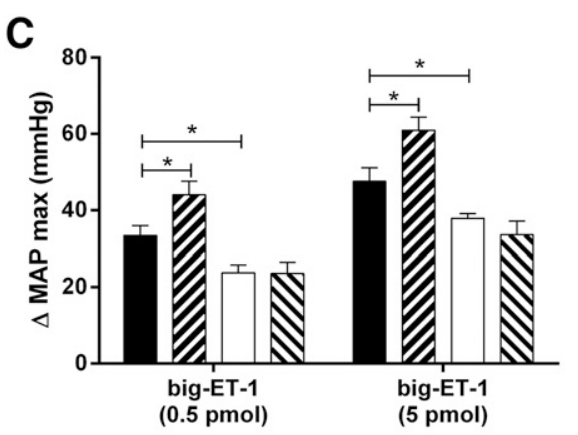

intrathecal treatment

$\mathbf{E}$

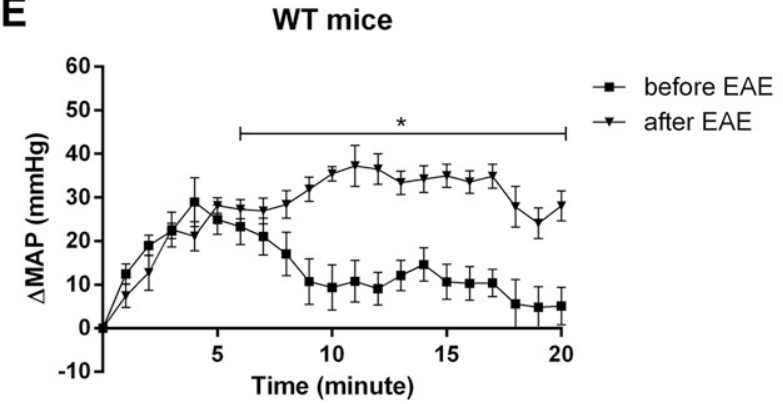

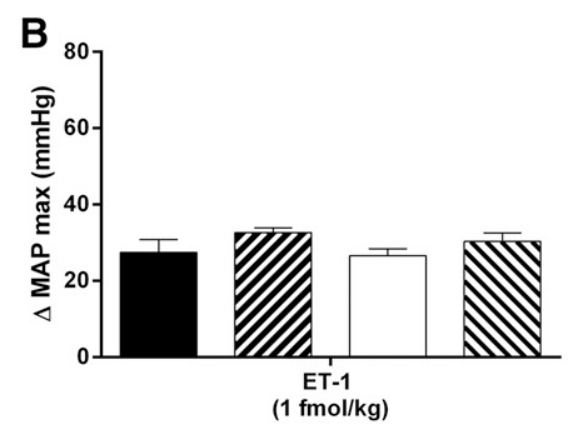

intravenous treatment

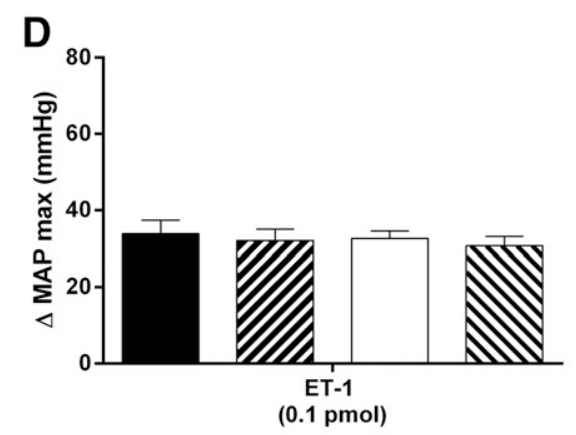

intrathecal treatment

$\mathbf{F}$

mMCP-4 KO mice

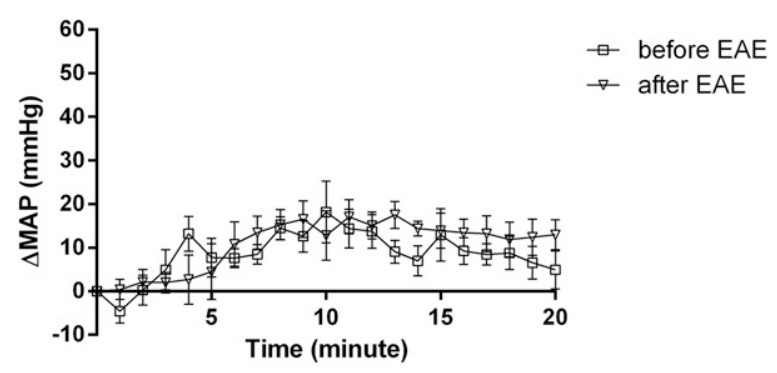

Fig. 3. Functional activity of chymase on maximal mean arterial pressor responses in a conscious WT or mMCP-4 KO mouse model of EAE to exogenous big-ET-1 administered systemically by intravenous injection via caudal vein (A), ET-1 administered intravenously (B), big-ET-1 centrally administered by intrathecal injection (C), and ET-1 administered intrathecally (D). (E) Time-course profile to intrathecally administered big-ET-1 (0.5 pmol/mouse) in healthy (closed square) or post-EAE (closed triangle) WT mice. (F) Time-course profile to intrathecally administered big-ET-1 (0.5 pmol/mouse) in healthy (open squares) or EAE (open triangles) mMCP-4 KO mice. Each bar or point represents the mean \pm S.E.M. of MAP maximal increase for $n=4-8$ mice by group. $* P<0.05$; ** $P<0.01$; *** $P<0.001$ compared with the healthy WT group.

healthy WT $=1.00 \pm 0.58$, WT EAE $=0.76 \pm 0.38$, healthy $\mathrm{mMCP}-4 \mathrm{KO}=0.93 \pm 0.70$, and $\mathrm{mMCP}-4 \mathrm{KO} \mathrm{EAE}=0.79 \pm$ 0.61) (data not shown).

We also evaluated the mRNA expression of the $\mathrm{ET}_{\mathrm{A}}$ or $\mathrm{ET}_{\mathrm{B}}$ receptors in lung and brain extracts. In the brain, we did not observe any change in the expression of these two receptors $\left(\mathrm{ET}_{\mathrm{A}}\right.$ : healthy WT $=1.00 \pm 0.36, \mathrm{WT} \mathrm{EAE}=1.28 \pm 0.44$, healthy $\mathrm{mMCP}-4 \mathrm{KO}=1.18 \pm 0.28$, and $\mathrm{mMCP}-4 \mathrm{KO} \mathrm{EAE}=1.07 \pm$ $0.46 ; \mathrm{ET}_{\mathrm{B}}$ : healthy WT $=1.00 \pm 0.07, \mathrm{WT} \mathrm{EAE}=1.09 \pm 0.12$, healthy mMCP-4 KO $=1.01 \pm 0.06$, and mMCP-4 KO EAE $=$ $1.02 \pm 0.17)$. Furthermore, no significant differences were found in the pulmonary expression of ET-1 receptors between WT and mMCP-4 KO mice or between these two groups after EAE immunization $\left(\mathrm{ET}_{\mathrm{A}}\right.$ : healthy $\mathrm{WT}=1.00 \pm 0.60$, WT EAE $=$ $1.04 \pm 1.25$, healthy mMCP-4 KO $=1.34 \pm 0.34$, and mMCP-4 $\mathrm{KO} \mathrm{EAE}=1.55 \pm 0.71 ; \mathrm{ET}_{\mathrm{B}}$ : healthy WT $=1.00 \pm 0.50, \mathrm{WT}$ $\mathrm{EAE}=1.62 \pm 1.10$, healthy $\mathrm{mMCP}-4 \mathrm{KO}=1.20 \pm 0.45$, and mMCP-4 KO EAE $=1.74 \pm 0.60)$ (data not shown).
Increased mRNA Expression of Pulmonary IL-33 in mMCP-4 KO Mice. We also investigated if EAE has an impact on mRNA levels of IL-33. As seen in Fig. 5B, no significant differences were found in cerebral IL-33 mRNA levels in the WT EAE-immunized group or in mMCP-4 KO mice when compared with baseline levels in healthy WT mice. In contrast, increased expression of IL-33 mRNA in the lung was measured in healthy mMCP-4 KO $(P<0.01)$ as well as in mMCP-4 KO 1 week post-EAE mice when compared with baseline levels in healthy WT mice $(P<0.001)$. Notably, we observed greater expression of IL-33 in the healthy WT brain compared with healthy WT lungs (3167-fold) (data not shown).

EAE Has No Influence on ET-1 and IL-33 Tissue Levels but Increases Serum TNF- $\alpha$ in mMCP-4 KO Mice. Albeit basal levels of ET-1 (in pulmonary tissues) and IL-33 (in brains and lungs) were measured, no significant changes were prompted by EAE in the same type of tissues of WT or mMCP-4 KO mice (Supplemental Tables 1 and 2). 
A
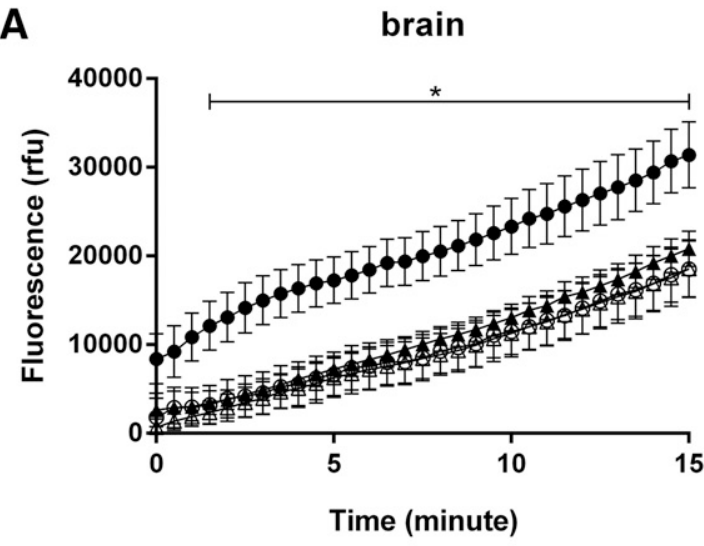

B

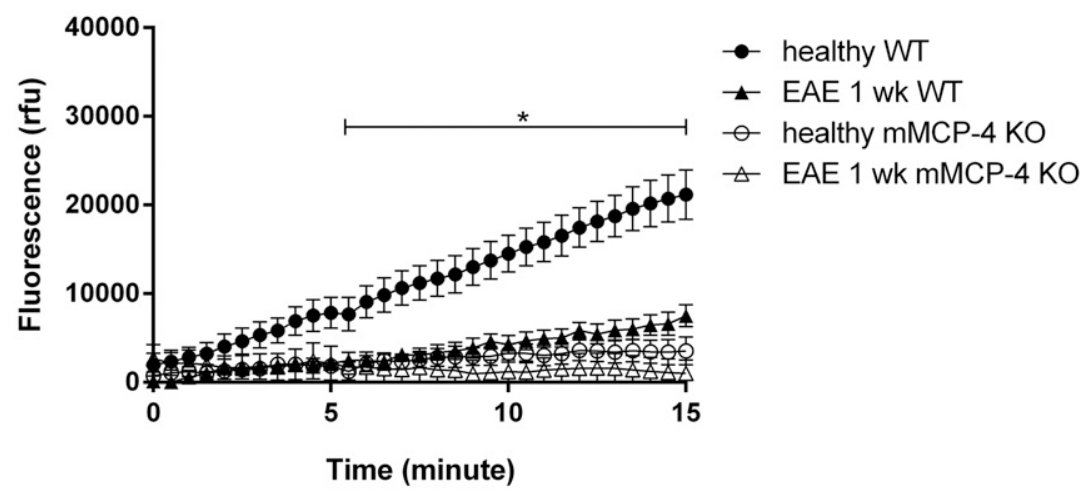

C

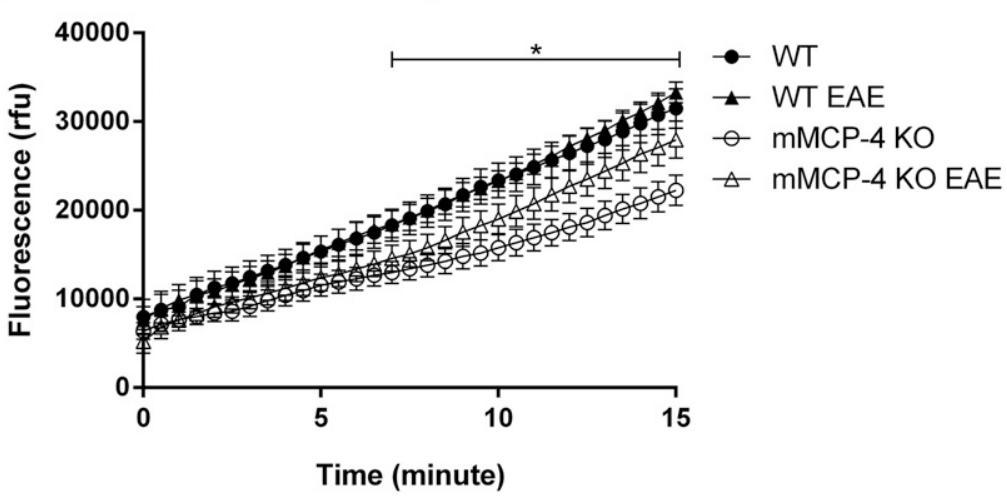

Fig. 4. Chymotrypsin-like activity measured ex vivo from healthy and 1 week post-EAE WT and mMCP-4 $\mathrm{KO}$ mice as increased fluorescence after substrate succinyl-Leu-Leu-Val-Tyr-7-amino-4-methylcoumarin cleavage in brain homogenates (A), peritoneal mast cells (B), and lung homogenates (C). Each point represents the mean \pm S.E.M. of $n=6-9$ independent experiments realized in duplicate. ${ }^{*} P<0.05$ compared with healthy WT mice.
In addition, TNF- $\alpha$ in brain or lung tissue homogenates from healthy WT or mMCP-4 KO mice was undetectable (data not shown). TNF- $\alpha$ was also nondetectable in serum from healthy WT mice (Fig. 6). Finally, albeit low serum levels of TNF- $\alpha$ were measured in WT mice 1 week post-EAE and healthy mMCP-4 KO congeners $(5.96 \pm 4.69$ and $3.65 \pm 3.11 \mathrm{pg} / \mathrm{ml}$, respectively) a 4-fold increase in TNF- $\alpha$ was observed in serum samples of mMCP-4 KO 1 week post-EAE immunization versus healthy mMCP-4 KO congeners $(21.21 \pm 7.82 \mathrm{pg} / \mathrm{ml}$; $P<0.05$ ) (Fig. 6).

\section{Discussion}

In the present study, we show that both systemic and intrathecal administration of big-ET-1 and ET-1 trigger a sustained increase in blood pressure with little effect on heart rate in conscious mice. In addition, induction of EAE selectively potentiates the pressor response to the precursor big-ET-1 in an mMCP-4-sensitive fashion and prompts MC degranulation and loss of chymase activity in the brain but not in the lungs. Finally, at very early stages of EAE, increases in the expression of IL-33 and serum levels of TNF- $\alpha$ were detected in the periphery but not in the CNS of mMCP-4 KO mice.

These results suggest that mMCP-4-driven events prompted by EAE occur within and outside the CNS in the mouse model. Previous studies demonstrated that EAE, actively induced in $\mathrm{C} 57 \mathrm{Bl} / 6$ mice with myelin oligodendrocyte glycoprotein-35-55, was associated with perivascular inflammation, activation of T cells, CD4+ and mononuclear cells, and subsequent axonal demyelination leading to progressive/ ascending hind limb paralysis (Miller et al., 2007). Relevant to 

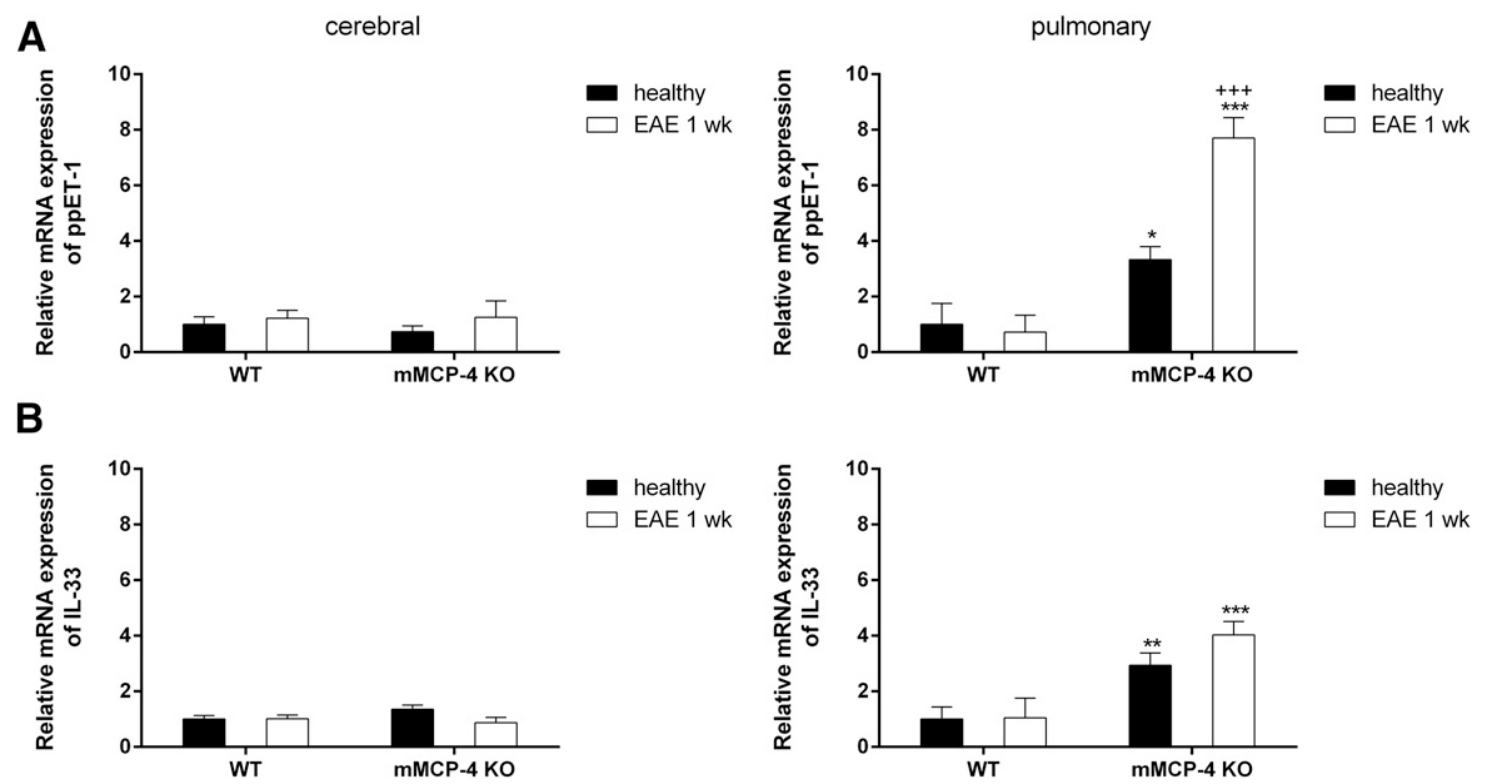

Fig. 5. mRNA relative expression from healthy mice (closed bars) and mice after 1 week EAE immunization (open bars) in brain extracts (left panels) or lung extracts (right panels) for the prepro-ET-1 gene (A) or IL-33 gene (B). Each bar represents the mean \pm S.E.M. of $n=6-12$ separate experiments. ${ }^{*} P<0.05 ; * * P<0.01 ; * * * P<0.001$ compared with healthy WT mice and ${ }^{+++} P<0.001$ compared with healthy mMCP-4 KO mice.

the present study, Odoardi et al. (2012) were the first to demonstrate that in MS transiently airway-residing $\mathrm{T}$ cells reprogram their gene expression and alter their surface expression of adhesion molecules responsible for subsequent migration in cerebral blood vessels. Based on the previously described observations, EAE may have a significant impact on non-CNS inflammatory processes.

Since it is established that mMCP-4 is involved in the production of ET-1 from big-ET-1 in vitro and in vivo (Fecteau et al., 2005; Simard et al., 2009; Houde et al., 2013; Semaan et al., 2015), we investigated the influence of EAE on the acute activity of this particular enzyme, both centrally and in the periphery. We have previously reported that mMCP-4 is responsible for $50 \%$ of the pulmonary content of ET-1 (Houde et al., 2013). Furthermore, we also reported a reduction in clinical signs and brain levels of ET-1 in mMCP-4 KO mice subjected to EAE, suggesting a role for this protease in the early phases of the neurodegenerative disease (Desbiens et al., 2016).

Interestingly, EAE triggered an increase in mMCP-4 activity in the CNS as well as in the periphery since the

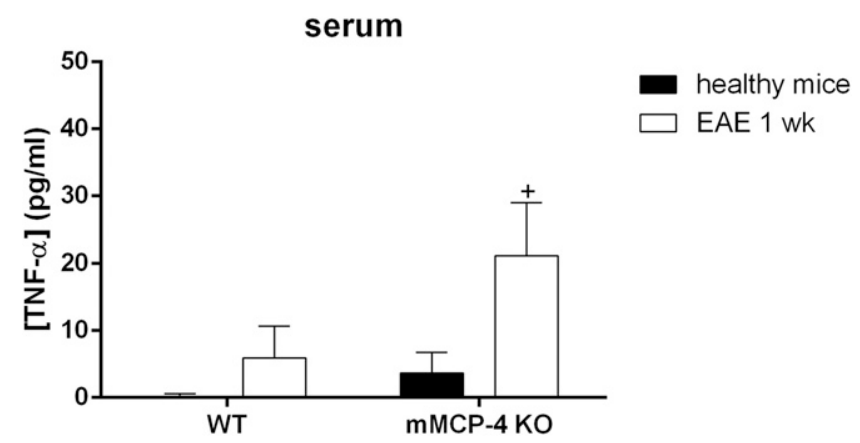

Fig. 6. Quantification of serum TNF- $\alpha$ in healthy WT or mMCP-4 KO mice (closed bars) and WT or mMCP-4 KO mice 1 week after EAE immunization (open bars). Each bar represents the mean \pm S.E.M. of WT $(n=6)$ and mMCP-4 KO $(n=11$ or 12$)$ mice. ${ }^{+} P<0.05$ comparing EAE to healthy mMCP-4 KO mice. dose-dependent responses to big-ET-1, but not to ET-1 (administered intrathecally or intravenously), triggered significant increases in mean arterial pressure in conscious WT but not mMCP-4 KO mice. To our knowledge, this is the first study comparing the central versus systemic pressor properties of vasoactive peptides in conscious mice. As previously shown in the rat model (Poulat et al., 1994), ganglionic blockade with pentolinium significantly reduced basal mean arterial blood pressure and heart rate, but did not alter the pressor responses to ET-1 (data not shown); a possible indication that the blood pressure and heart rate were maintained by vagal reflex through the sympathetic nervous system.

Albeit, the characterization of central ET receptors has previously been reported in EAE mice, antagonists were not used in the present study since the expression of these receptors was not affected in our model and the pressor responses to ET-1 (administered centrally or intravenously) were not affected under any of the conditions tested. It is also of interest that mRNA levels for the prepro-ET-1 but not for any other components of the ET pathway, were enhanced in the lungs but not the cerebral tissues of EAE mice knocked out for the mMCP-4 gene. In line with these findings, we have previously shown that repression of the chymase gene abolished the increase in brain immunoreactive ET-1 after 1 week post-EAE (Desbiens et al., 2016). In addition, mMCP-4 KO mice show reduced basal levels of the same peptide in the lungs (Houde et al., 2013), suggesting that the increased expression of the precursor of ET-1 reflects a compensatory mechanism for the alternate production of ET-1 in proinflammatory conditions in the respiratory tract.

We have previously shown that MCs of murine or human origin release hydrolytically active chymase generating the intermediate ET-1 (1-31) from its precursor big-ET-1 (Semaan et al., 2015). Therefore, it is of interest that EAE prompts release of mMCP-4 from peritoneal MCs as well as in the brain but not in the lungs. These results support a role for MC-derived 
chymase both centrally and in the periphery in the MS mouse model. The absence of chymase-specific hydrolysis in lungs suggests that EAE-prompted differentiation of T cells in the airways has little impact on MC-derived mMCP-4 in the pulmonary system. Thus, the source of big-ET-1 hydrolysis to ET-1 in the systemic circulation may be found elsewhere than in resident MCs located in the airways. Thus, our results suggest that the inflammatory process triggered by EAE enhances mMCP-4-like activity in the compartments more involved in the control of vascular resistance rather than in pulmonary vessels. Notwithstanding the absence of detectable pulmonary chymase activity post-EAE, it is of interest that enhanced expression of IL-33 mRNA in lungs derived from mMCP-4 KO mice when compared with WT congeners; a phenomenon further enhanced by EAE in our study. To our knowledge, there is no reported evidence of a direct effect of this particular chymase isoform on the expression of IL-33. However, it was shown in a previous study that IL-33 protein is a preferred substrate for mMCP-4 proteolytic activity (Waern et al., 2013).

Among several other cytokines, TNF- $\alpha$ upregulates the expression of IL-33 via extracellular signal-regulated kinase and p38 pathways in primary nasal epithelial and A549 cells (Park et al., 2016) and via phosphoinositide-3-kinase and c-Jun N-terminal kinase pathways in nasal fibroblasts (Nomura et al., 2012), leading in both cases to activation of nuclear factor- $\kappa \mathrm{B}$ (Nomura et al., 2012; Park et al., 2016). In addition, TNF- $\alpha$ is a substrate for the chymase mMCP-4 (Piliponsky et al., 2012). Interestingly, TNF- $\alpha$ was increased significantly in serum derived from mMCP-4 KO versus WT mice subjected to EAE. We suggest that the latter cytokine is involved in the increased expression of IL-33. This mechanism, in conditions of EAE, appears to be limited to the respiratory tract as opposed to the CNS. Finally, we suggest that 1 week of EAE is too short a period to trigger significant increases in IL-33 or ET-1 proteins in the lungs and the former in the brain as well. However, it is of interest that cardiovascular phenotypes triggered by EAE were identified in this study even at such an early stage of the disease.

One limitation of the present study is that the direct impact of anti-TNF- $\alpha$ blockers on the expression of IL-33 in EAE mice was not assessed. However, considering that TNF- $\alpha$ blockers have recently been counterindicated in MS patients due to the demyelination properties of these molecules (van Oosten et al., 1996; The Lenercept Multiple Sclerosis Study Group and The University of British Columbia MS/MRI Analysis Group, 1999; Probert, 2015), the present study provides mechanistic insights into why TNF- $\alpha$ should be left intact in this particular neurodegenerative disease.

We have previously reported a significant role for mMCP-4 in EAE (Desbiens et al., 2016). The results from the present study now suggest that mMCP-4-dependent hydrolysis of vasoactive and neurogenic peptides such as ETs is enhanced in the periphery and CNS at least in this murine model of MS. If our results in the mouse model are translatable to the human disease, chymase inhibitors may be useful in reducing neurogenic decay as well as overall systemic inflammation in MS patients.

\section{Acknowledgments}

We thank Dr. Réjean Couture (Université de Montréal, Quebec, Canada) and Dr. Alain Frigon (Université de Sherbrooke, Quebec,
Canada) for useful discussionsas well as Dr Jean-Bernard Denault (Université de Sherbrooke, Quebec, Canada) for the use of the Infinite M1000 spectrophotometer.

\section{Authorship Contributions}

Participated in research design: D’Orléans-Juste, Desbiens, Gris, Gharagozloo.

Conducted experiments: Desbiens, Lapointe, Gendron, Gharagozloo, Vincent.

Performed data analysis: Desbiens, Lapointe, Vincent.

Wrote or contributed to the writing of the manuscript: D'OrléansJuste, Desbiens, Gris, Pejler, Gendron, Gharagozloo, Lapointe, Vincent.

\section{References}

Balato A, Di Caprio R, Canta L, Mattii M, Lembo S, Raimondo A, Schiattarella M, Balato N, and Ayala F (2014) IL-33 is regulated by TNF- $\alpha$ in normal and psoriatic skin. Arch Dermatol Res 306:299-304.

Ben-Nun A, Kaushansky N, Kawakami N, Krishnamoorthy G, Berer K, Liblau R, Hohlfeld R, and Wekerle H (2014) From classic to spontaneous and humanized models of multiple sclerosis: impact on understanding pathogenesis and drug development. $J$ Autoimmun 54:33-50.

Borland JA, Kelsall C, Yacoub MH, and Chester AH (2005) Expression, localisation and function of ACE and chymase in normal and atherosclerotic human coronary arteries. Vascul Pharmacol 42:99-108.

Cheng Y, Sun L, Xie Z, Fan X, Cao Q, Han J, Zhu J, and Jin T (2017) Diversity of immune cell types in multiple sclerosis and its animal model: pathological and therapeutic implications. J Neurosci Res 95:1973-1983.

Compston A and Coles A (2008) Multiple sclerosis. Lancet 372:1502-1517.

Desbiens L, Lapointe C, Gharagozloo M, Mahmoud S, Pejler G, Gris D, and D'Orléans-Juste P (2016) Significant contribution of mouse mast cell protease 4 in early phases of experimental autoimmune encephalomyelitis. Mediators Inflamm 2016:9797021.

D'haeseleer M, Beelen R, Fierens Y, Cambron M, Vanbinst AM, Verborgh C, Demey $\mathrm{J}$, and De Keyser $\mathrm{J}$ (2013) Cerebral hypoperfusion in multiple sclerosis is reversible and mediated by endothelin-1. Proc Natl Acad Sci USA 110:5654-5658.

Dreyer L, Magyari M, Laursen B, Cordtz R, Sellebjerg F, and Locht H (2016) Risk of multiple sclerosis during tumour necrosis factor inhibitor treatment for arthritis: a population-based study from DANBIO and the Danish Multiple Sclerosis Registry. Ann Rheum Dis 75:785-786.

Duffy SS, Lees JG, and Moalem-Taylor G (2014) The contribution of immune and glial cell types in experimental autoimmune encephalomyelitis and multiple sclerosis. Mult Scler Int 2014:285245.

Ewanchuk BW, Gharagozloo M, Peelen E, and Pilutti LA (2018) Exploring the role of physical activity and exercise for managing vascular comorbidities in people with multiple sclerosis: a scoping review. Mult Scler Relat Disord 26:19-32.

Fairbanks CA (2003) Spinal delivery of analgesics in experimental models of pain and analgesia. Adv Drug Deliv Rev 55:1007-1041.

Fecteau MH, Honoré JC, Plante M, Labonté J, Rae GA, and D’Orléans-Juste P (2005) Endothelin-1 (1-31) is an intermediate in the production of endothelin-1 after big endothelin-1 administration in vivo. Hypertension 46:87-92.

Feyerabend TB, Weiser A, Tietz A, Stassen M, Harris N, Kopf M, Radermacher P, Möller P, Benoist C, Mathis D, et al. (2011) Cre-mediated cell ablation contests mast cell contribution in models of antibody- and T cell-mediated autoimmunity. Immunity 35:832-844

Hammond TR, McEllin B, Morton PD, Raymond M, Dupree J, and Gallo V (2015) Endothelin-B receptor activation in astrocytes regulates the rate of oligodendrocyte regeneration during remyelination. Cell Rep 13:2090-2097.

Haufschild T, Shaw SG, Kesselring J, and Flammer J (2001) Increased endothelin-1 plasma levels in patients with multiple sclerosis. J Neuroophthalmol 21:37-38.

Hendrix S, Kramer P, Pehl D, Warnke K, Boato F, Nelissen S, Lemmens E, Pejler G, Metz M, Siebenhaar F, et al. (2013) Mast cells protect from post-traumatic brain inflammation by the mast cell-specific chymase mouse mast cell protease- 4 . FASEB J 27:920-929.

Houde M, Jamain MD, Labonté J, Desbiens L, Pejler G, Gurish M, Takai S, and D'Orléans-Juste P (2013) Pivotal role of mouse mast cell protease 4 in the conversion and pressor properties of big-endothelin-1. J Pharmacol Exp Ther 346: $31-37$.

Huang M, Allen DR, Keller DM, Fadel PJ, Frohman EM, and Davis SL (2016) Impaired carotid baroreflex control of arterial blood pressure in multiple sclerosis. $J$ Neurophysiol 116:81-87.

Jiang HR, Milovanović M, Allan D, Niedbala W, Besnard AG, Fukada SY, Alves-Filho JC, Togbe D, Goodyear CS, Linington C, et al. (2012) IL-33 attenuates EAE by suppressing IL-17 and IFN- $\gamma$ production and inducing alternatively activated macrophages. Eur J Immunol 42:1804-1814.

Kakizoe E, Shiota N, Tanabe Y, Shimoura K, Kobayashi Y, and Okunishi H (2001) Isoform-selective upregulation of mast cell chymase in the development of skin fibrosis in scleroderma model mice. J Invest Dermatol 116:118-123.

Kipp M, van der Star B, Vogel DY, Puentes F, van der Valk P, Baker D, and Amor S (2012) Experimental in vivo and in vitro models of multiple sclerosis: EAE and beyond. Mult Scler Relat Disord 1:15-28.

Link H (1998) The cytokine storm in multiple sclerosis. Mult Scler 4:12-15.

Lublin FD (2005) Clinical features and diagnosis of multiple sclerosis. Neurol Clin 23:1-15.

Luo C, Jian C, Liao Y, Huang Q, Wu Y, Liu X, Zou D, and Wu Y (2017) The role of microglia in multiple sclerosis. Neuropsychiatr Dis Treat 13:1661-1667. 
Miller SD, Karpus WJ, and Davidson TS (2007) Experimental autoimmune encephalomyelitis in the mouse. Curr Protoc Immunol Chapter 15:Unit 15.1.

Mincu RI, Magda SL, Mihaila S, Florescu M, Mihalcea DJ, Velcea A, Chiru A, Tiu C Popescu BO, Cinteza M, et al. (2018) Impaired cardiac function in patients with multiple sclerosis by comparison with normal subjects. Sci Rep 8:3300.

Moore JE III and James GW III (1953) A simple direct method for absolute basophil leucocyte count. Proc Soc Exp Biol Med 82:601-603.

Nomura K, Kojima T, Fuchimoto J, Obata K, Keira T, Himi T, and Sawada N (2012) Regulation of interleukin-33 and thymic stromal lymphopoietin in human nasal fibroblasts by proinflammatory cytokines. Laryngoscope 122:1185-1192.

Odoardi F, Sie C, Streyl K, Ulaganathan VK, Schläger C, Lodygin D, Heckelsmiller K, Nietfeld W, Ellwart J, Klinkert WE, et al. (2012) T cells become licensed in the lung to enter the central nervous system. Nature 488:675-679.

Pache M, Kaiser HJ, Akhalbedashvili N, Lienert C, Dubler B, Kappos L, and Flammer J (2003) Extraocular blood flow and endothelin-1 plasma levels in patients with multiple sclerosis. Eur Neurol 49:164-168.

Park IH, Park JH, Shin JM, and Lee HM (2016) Tumor necrosis factor- $\alpha$ regulates interleukin-33 expression through extracellular signal-regulated kinase, p38, and nuclear factor $-\kappa \mathrm{B}$ pathways in airway epithelial cells. Int Forum Allergy Rhinol 6:973-980

Petrie MC, Padmanabhan N, McDonald JE, Hillier C, Connell JM, and McMurray J. (2001) Angiotensin converting enzyme (ACE) and non-ACE dependent angiotensin II generation in resistance arteries from patients with heart failure and coronary heart disease. J Am Coll Cardiol 37:1056-1061.

Piliponsky AM, Chen CC, Rios EJ, Treuting PM, Lahiri A, Abrink M, Pejler G, Tsai M, and Galli SJ (2012) The chymase mouse mast cell protease 4 degrades TNF, limits inflammation, and promotes survival in a model of sepsis. Am J Pathol 181 875-886.

Ponath G, Park C, and Pitt D (2018) The role of astrocytes in multiple sclerosis. Front Immunol 9:217.

Poulat P, D'Orléans-Juste P, de Champlain J, Yano M, and Couture R (1994) Cardiovascular effects of intrathecally administered endothelins and big endothelin-1 in conscious rats: receptor characterization and mechanism of action. Brain Res 648:239-248

Probert L (2015) TNF and its receptors in the CNS: the essential, the desirable and the deleterious effects. Neuroscience 302:2-22.

Secor VH, Secor WE, Gutekunst CA, and Brown MA (2000) Mast cells are essential for early onset and severe disease in a murine model of multiple sclerosis. $J$ Exp Med 191:813-822.
Semaan W, Desbiens L, Houde M, Labonté J, Gagnon H, Yamamoto D, Takai S, Laidlaw T, Bkaily G, Schwertani A, et al. (2015) Chymase inhibitor-sensitive synthesis of endothelin-1 (1-31) by recombinant mouse mast cell protease 4 and human chymase. Biochem Pharmacol 94:91-100.

Shin T, Kang B, Tanuma N, Matsumoto Y, Wie M, Ahn M, and Kang J (2001) Intrathecal administration of endothelin-1 receptor antagonist ameliorates autoimmune encephalomyelitis in Lewis rats. Neuroreport 12:1465-1468.

Simard E, Jin D, Takai S, Miyazaki M, Brochu I, and D'Orléans-Juste P (2009) Chymase-dependent conversion of big endothelin-1 in the mouse in vivo. $J$ Pharmacol Exp Ther 328:540-548.

Tanzola MB, Robbie-Ryan M, Gutekunst CA, and Brown MA (2003) Mast cells exert effects outside the central nervous system to influence experimental allergic encephalomyelitis disease course. J Immunol 171:4385-4391.

Tchougounova E, Pejler G, and Abrink M (2003) The chymase, mouse mast cell protease 4 , constitutes the major chymotrypsin-like activity in peritoneum and ear tissue. A role for mouse mast cell protease 4 in thrombin regulation and fibronectin turnover. J Exp Med 198:423-431.

The Lenercept Multiple Sclerosis Study Group and The University of British Columbia MS/MRI Analysis Group (1999) TNF neutralization in MS: results of a randomized, placebo-controlled multicenter study. Neurology 53: $457-465$

van Oosten BW, Barkhof F, Truyen L, Boringa JB, Bertelsmann FW, von Blomberg BM, Woody JN, Hartung HP, and Polman CH (1996) Increased MRI activity and immune activation in two multiple sclerosis patients treated with the monoclonal anti-tumor necrosis factor antibody cA2. Neurology 47:1531-1534.

Waern I, Lundequist A, Pejler G, and Wernersson S (2013) Mast cell chymase modulates IL-33 levels and controls allergic sensitization in dust-mite induced airway inflammation. Mucosal Immunol 6:911-920.

Xiao Y, Lai L, Chen H, Shi J, Zeng F, Li J, Feng H, Mao J, Zhang F, Wu N, et al. (2018) Interleukin-33 deficiency exacerbated experimental autoimmune encephalomyelitis with an influence on immune cells and glia cells. Mol Immunol 101: $550-563$.

Address correspondence to: Pedro D’Orléans-Juste, Department of Pharmacology and Physiology, Université de Sherbrooke, 3001, 12e Avenue Nord, Sherbrooke, QC, Canada J1H 5N4. E-mail: labpdj@usherbrooke.ca 